\title{
ASSESSMENT OF TOXICITY AND ANAEROBIC DEGRADATION OF ANTI-OSMOTIC DRUG BASED PHARMACEUTICAL EFFLUENT IN AN UPFLOW ANAEROBIC FLUIDIZED BED SYSTEM
}

\section{R. SARAVANANE* \\ D.V.S. MURTHY and \\ K. KRISHNAIAH}

Indian Institute of Technology, Madras Department of Chemical Engineering

Environmental Engineering Laboratory

Chennai - 600 036, India

*to whom all correspondence should be addressed e-mail: perusara@yahoo.com

Received: 24/01/00

fax: $+91-44-2430957$

\section{ABSTRACT}

During the production of cephradine (a main constituent of anti-osmotic drug) a large quantity of concentrated effluent was produced. The main polluting compounds in this effluent are osmotic drug, acetic acid and ammonia. The main objectives of the study were to assess the toxicity in terms of specific methanogenic activity on anaerobic degradation of cephradine with Volatile Fatty Acid (VFA) as co-substrate in batch systems using adapted and non-adapted cultures and to study the effect of bioaugmentation with adapted and non-adapted cultures on anaerobic treatment of anti-osmotic drug based pharmaceutical effluent in continuous mode using a fluidised bed reactor. The toxicity assessment was measured in terms of specific methanogenic activity $\left(\mathrm{ml} \mathrm{CH}_{4} \mathrm{~g}^{-1} \mathrm{VSS} \mathrm{d}^{-1}\right)$, which was found to decrease with increase in cephradine concentration and attained a maximum at $100 \mathrm{mg} \mathrm{l}^{-1}$. The COD reduction (\%) in continuous mode reached maximum of 88.5 at a Hydraulic Retention Time (HRT) of $12 \mathrm{~h}$ using bioaugmentation through periodic addition of 14 to $20 \mathrm{~g} \mathrm{l}^{-1}$ of biomass (acclimated cells) every 2 days from an off-line enricher-reactor.

KEY WORDS: Toxicity, Bioaugmentation, Enricher reactor, Anti-osmotic pharmaceutical effluent, Anaerobic, Fluidized bed reactor.

\section{INTRODUCTION}

Pharmaceutical industries, mainly anti-osmotic and synthetic drug based industries suffer from inadequate effluent treatment due to the presence of toxic substances and complex biomass formed during the secondary treatment process. Aromatic compounds such as phenols and methylated phenyls are commonly encountered pollutants, originating typically from modern industrial activities. Because of their bacterial toxicity and recalcitrance, when present in wastewaters, they play a key role in decreasing COD removal rates in treatment systems. As a result of their toxicity and despite their usually relatively low concentration, their removal from contaminated effluents is as important as removal of the COD fraction.

Bioaugmentation refers to a method of maintaining sufficient biomass when adequate carbon substrates and nutrients are unavailable in the effluent. Bioaugmentation using purchased cells 
(Babcock et al., 1992) could not find evidence of successful operation with respect to anaerobic degradation of industrial effluents. The present work adapts the methodology suggested by earlier investigators (Cardinal and Stenstrom, 1991) using suspended cultures, where an off-line reactor, called an enricher- reactor, was used on-site to grow cells specifically prepared for use in the main (anaerobic fluidized bed) reactor. The enricher-reactor operates separately and under different conditions from the main reactor. The substrates being fed to the enricher-reactor can be the same as in the main reactor designed to induce the desired operation in the enricher-reactor (Babcock and Stenstrom, 1993; Babcock et al., 1993). The biomass was produced within the enricher- reactor where optimum growth conditions were maintained and growth- supporting substrates were added. The cells produced in the enricher-reactor were viable in the main reactor for several generations, which enhanced the biomass concentration. The acclimated cells could be either continuously or intermittently transferred to the main reactor, and an adequate increase in biomass can be maintained. The increased biomass can be maintained to increase treatment efficiency, or less frequently augmented to prevent washout or maintain the desired organism condition of acclimation to a specific substrate or wastewater.

Anaerobic degradation of different constituents of antibiotic and synthetic drug based effluents were recently been carried out, using methanogenic organisms (Bisaillon et al., 1993; Haggblom et al., 1990; Roberts and Fedorak, 1987; Roberts et al., 1990), sulphate reducing organisms (Haggblom et al., 1990; Ramanand and Suflita, 1991, 1993; Suflita et al., 1989), nitrate reducing organisms (Bossert et al., 1986; Tschech and Fuchs, 1987) and iron reducing organisms (Lovely and Lonergan, 1990).

In this investigation, the assessment of toxicity was carried out in terms of specific methanogenic activity on anaerobic degradation of cephradine with Volatile Fatty Acid (VFA) as co-substrate in batch systems using adapted and non-adapted cultures. The effect of bioaugmentation was studied on anaerobic treatment of anti-osmotic drug based pharmaceutical effluent in continuous mode with adapted and non-adapted cultures using a fluidised bed reactor.

\section{MATERIALS AND METHODS Industrial Effluent}

The pharmaceutical effluent (real effluent) was procured from M/s Orchid Pharmaceutical Private Ltd, Chennai (India). The effluent was analyzed as per the Standard Method (APHA, 1995) and the characteristics are shown in Table 1.

\section{Carrier Material}

Activated carbon particles of average size $700 \mathrm{~mm}$ and density $1500 \mathrm{~kg} \mathrm{~m}^{-3}$ were used as carrier material with static bed porosity of 0.38 . The bed material of $2 \mathrm{~kg}$ of carbon was loaded in the reactor corresponding to a static bed height to diameter $(\mathrm{H} / \mathrm{D})$ ratio of 1.5 .

\section{Seed and Inoculum}

Culture A (adapted culture) is a mixed sludge obtained from the anaerobic treatment plant (supernatant of anaerobic digester) and a secondary sludge from the anti-osmotic effluent treatment plant. Culture B (non-adapted) was obtained from an anaerobic digester treating municipal sewage located at Kodangaiyur, in Chennai, India.

\section{Medium Composition}

The medium contained $3 \mathrm{ml} \mathrm{l}^{-1}$ of a nutrient solution composed of $\left(\mathrm{g} \mathrm{l}^{-1}\right): \mathrm{KH}_{2} \mathrm{PO}_{4}(5.0), \mathrm{NH}_{4} \mathrm{Cl}$ (27), $\mathrm{MgSO}_{4}$ (1.2), $\mathrm{CaCl}_{2} \cdot 2 \mathrm{H}_{2} \mathrm{O}$ (0.12). It contained also $0.3 \mathrm{ml} \mathrm{l}^{-1}$ of a micronutrients solution and, where required, volatile fatty acids as substrates mixture. The mixture of VFA was composed of (final concentrations, $\mathrm{g} \mathrm{l}^{-1}$ ) acetate (2) propionate (0.5) and butyrate (0.5). The solution of micronutrients was composed of $\left(\mathrm{mg} \mathrm{l}^{-1}\right): \mathrm{H}_{3} \mathrm{BO}_{3}$ (50), $\mathrm{FeCl}_{3} \cdot 4 \mathrm{H}_{2} \mathrm{O}$ (2000), $\mathrm{ZnCl}_{2}(50), \mathrm{MnCl}_{2} \cdot 4 \mathrm{H}_{2} \mathrm{O}$ (500), $\mathrm{CuCl}_{2} \cdot \mathrm{H}_{2} \mathrm{O}(30),\left(\mathrm{NH}_{4}\right)_{6} \mathrm{Mo}_{7} \mathrm{O}_{24} \cdot 4 \mathrm{H}_{2} \mathrm{O}$ (50), $\mathrm{AlCl}_{3} \cdot 6 \mathrm{H}_{2} \mathrm{O}(90), \mathrm{CoCl}_{2} \cdot 6 \mathrm{H}_{2} \mathrm{O}(2000), \mathrm{NiCl}_{2} \cdot 6 \mathrm{H}_{2} \mathrm{O}$ (50), $\mathrm{Na}_{2} \mathrm{SeO}_{3} \cdot 5 \mathrm{H}_{2} \mathrm{O}$ (100), EDTA (1000), $\mathrm{HCl}$ $(36 \%)\left(1 \mathrm{ml} \mathrm{l}^{-1}\right)$. The water used this preparation is double distilled water. The water used for all other analyses is distilled water only.

\section{Analytical methods}

Ecotoxicity of the medium was checked using a Microtox model 500. Ecotoxicity evaluation is based on the measurement of inhibition of light emission by the bacterium Photobacterium phosphoreum in the presence of toxic compounds in the medium. The effluent to be tested was diluted and mixed with dilution water containing Photobacterium phospho- 
Table 1. Characteristics of pharmaceutical industrial effluent

\begin{tabular}{clc}
\hline Sl.No. & Characteristics & Value \\
\hline 1. & Flow rate $\left(\mathrm{m}^{3} \mathrm{~d}^{-1}\right)$ & 350 \\
2. & $\mathrm{pH}$ & $3-4$ \\
3. & Temperature $\left({ }^{\circ} \mathrm{C}\right)$ & $25-45$ \\
4. & COD $\left(\mathrm{mg} \mathrm{l}^{-1}\right)$ & $12000-15000$ \\
5. & BOD5 $\left(\mathrm{mg} \mathrm{l}^{-1}\right)$ & 2000 \\
6. & Cephradine $\left(\mathrm{mg} \mathrm{l}^{-1}\right)$ & $200-315$ \\
7. & Total Suspended Solids $\left(\mathrm{mg} \mathrm{l}^{-1}\right)$ & 6000 \\
8. & Total Dissolved Solids $\left(\mathrm{mg} \mathrm{l}^{-1}\right)$ & $11000-18500$ \\
9. & Total Volatile Solids $\left(\mathrm{mg} \mathrm{l}^{-1}\right)$ & 7500 \\
10. & $\mathrm{NH}_{3}\left(\mathrm{mg} \mathrm{l}^{-1}\right)$ & $15-40$ \\
11. & Surfactants & $2-20$ \\
\hline
\end{tabular}

reum and the light output was measured after 5 and 15 minutes (Microbics Corp., 1988). Light output of the bacteria was compared between the control (0\% waste, $100 \%$ dilution water) and the dilutions. If a reduction in light output resulted, the value of EC50 (effective concentration - the concentration responsible for a $50 \%$ reduction in an observed phenomenon, which, in this case, was light output) was calculated (Arbuckle and Alleman, 1992).

Chemical oxygen demand of effluent was measured as per Standard Method (APHA, 1995). Volatile fatty acids (VFA) and the composition of the biogas were analysed by a gas chromatography (GC) on a Hewlett-Packard, model 5890 A, equipped with a flame ionization detector (FID). Cephradine, 7-amino-3-deacetoxycephalosporanicacid (7-ADCA) and penicillic acid were determined as described in British Pharmacopoeia, 1980 using an Infrared Spectrometer (Model M- 500). The temperature during all the measurements was found to vary from $28-33^{\circ} \mathrm{C}$.

\section{Batch and toxicity assays}

Batch activity and toxicity assays were determined in 2.51 with 21 working volume. Biodegradability assays, $1000 \mathrm{ml}$ medium was used. Biodegradability assays were carried out to assess any residual biomass activity of the medium in terms of methane production. Methane production was measured by displacement of an aqueous solution. For toxicity assays, various concentrations of cephradine were added to the medium and measuring the methane gas produced assessed specific methanogenic activity. The specific methanogenic activity is represented in terms of the volume of methane gas produced $(\mathrm{ml})$ per gram of biomass [g VSS (Volatile Suspended Solids)] per day $\left(\mathrm{ml} \mathrm{CH}_{4} \mathrm{~g}^{-1} \mathrm{VSS} \mathrm{d}^{-1}\right)$. Duplicate assays and several controls were also used. Controls included autoclaved inoculated flasks to check for any abiotic removal and flasks containing only distilled water instead medium but without carbon sources to estimate any residual biomass activity.

\section{Experimental Set-up}

A schematic diagram of the experimental set up is shown in Fig. 1. An anaerobic fluidized bed reactor consisted of a perspex column (4) made by joining two sections of different lengths of $750 \mathrm{~mm}$ internal diameter measuring to a height of $1200 \mathrm{~mm}$ of $5 \mathrm{~mm}$ thickness. Over this, an upper section of 150 $\mathrm{mm}$ diameter and $300 \mathrm{~mm}$ height was mounted to prevent carry over of suspended particles into the effluent and also to serve as a gas holder (5). The working volume of the reactor was 101 .

\section{Start-up of the Reactor}

The reactor was loaded with activated carbon and supernatant of digested sludge (Culture A), procured from Municipal Sewage Treatment Plant of Kodangaiyur, Chennai India. Culture A was used for start-up experiments under complete recycling conditions. After this, the sludge and the diluted pharmaceutical effluent (Culture B) were mixed to get a COD concentration of $250 \mathrm{mg} \mathrm{l}^{-1}$. The start-up experiments were also carried out with Culture B. The reactor was operated under total recycling conditions for one week before switching it over to continuous operation. The bed expansion was maintained at $25-30 \%$ during the entire start-up period by maintaining the fluidization velocity at $25 \mathrm{~m} \mathrm{hr}^{-1}\left[1.9 \mathrm{U}_{\mathrm{mf}}(1.9 \mathrm{x}\right.$ fluidization velocity $\left.\left(\mathrm{U}_{\mathrm{mf}}\right)\right]$. 


\section{Enricher-Reactor Operation}

The enricher-reactor operates as a complete recycle reactor and directly connected to the main reactor as shown in Fig. 1. Initially 7.81 of Culture A (adapted Culture) and nutrient solution of 1.81 were mixed and maintained in a complete recycle condition for 7 days. A mass of $14-20 \mathrm{~g} \mathrm{l}^{-1}$ of volatile suspended solid (VSS) was transferred from this enricher-reactor to the main reactor every 48 hrs. The cell mass (VSS) in the enricherreactor was kept constant by replenishment of Culture A and nutrient solution (in the same initial volumetric proportion). This is similar to the experimental study (Babcock et al., 1992) where a cell mass (VSS) of $14-20 \mathrm{~g} \mathrm{l}^{-1}$ was added every 2 days during start-up of the reactor. Adapted and non-adapted cultures were used for start-up to assess the effect of bioaugmentation. In the start- up experiments conducted using multiple inoculum, the volume (\%) of culture A was varied from 0 to $100 \%$ with volume of feed (pharmaceutical effluent) from 100 to $0 \%$. The volatile fatty acid (acetic acid) was varied from 0 to $2000 \mathrm{mg} \mathrm{l}^{-1}$. The total COD (Pharmaceutical effluent and acetic acid together) was found to vary from 250 to $4000 \mathrm{mg} \mathrm{l}^{-1}$. A mass of acclimated culture (VSS) of $14 \mathrm{~g} \mathrm{l}^{-1}$ was transferred from enricher-reactor to the main reactor every $48 \mathrm{hrs}$ with an intention to bioaugment the reactor. In the start-up experiments conducted using single inoculum, the volume (\%) of culture B (viz. supernatant of anaerobic digester) was varied from 0 to $100 \%$ with volume of feed (pharmaceutical effluent) from 100 to $0 \%$. The COD of the effluent was varied from 245 to $4000 \mathrm{mg} \mathrm{l}^{-1}$. The influent and effluent COD concentrations and biogas yield were monitored daily.

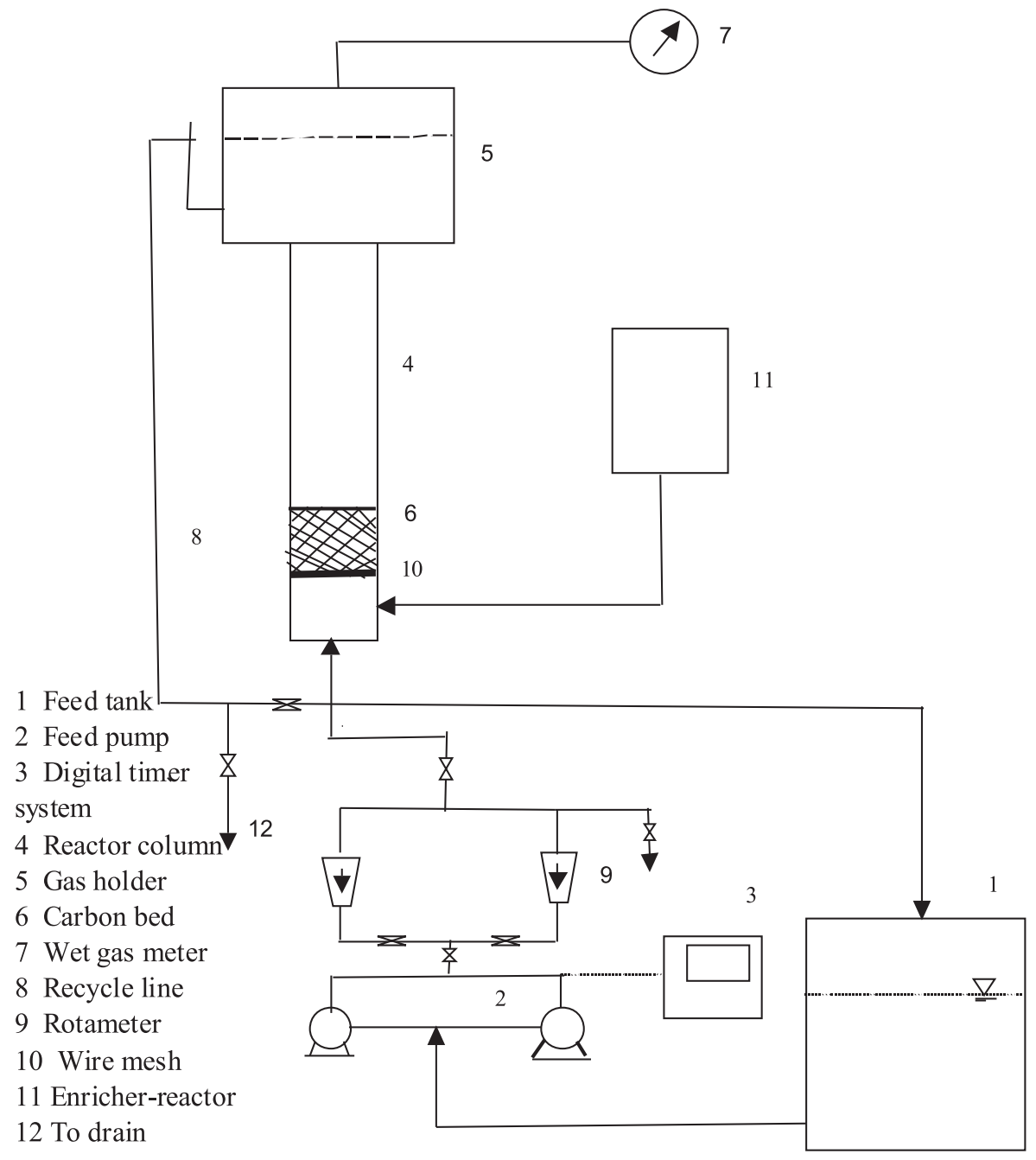

Figure 1. Experimental set-up of Anaerobic fluidized bed reactor. 
Table 2. The toxicity of cephradine in batch system Microtox testing

\begin{tabular}{c|cccc}
\hline \multirow{2}{*}{$\begin{array}{c}\text { Cephradine } \\
\text { concentration }\end{array}$} & \multicolumn{4}{|c}{ Microtox, EC50 } \\
\cline { 2 - 5 }$\left(\mathrm{mg} \mathrm{l}^{-1}\right)$ & 5 & 15 & 27 & 45 \\
\cline { 2 - 5 } & $\mathrm{N}^{\mathrm{a}}$ & $\mathrm{N}$ & $\mathrm{N}$ & $\mathrm{N}$ \\
50 & 57 & 44 & $\mathrm{~N}$ & $\mathrm{~N}$ \\
200 & 57 & $\mathrm{D}^{\mathrm{b}}$ & $\mathrm{D}$ & $\mathrm{D}$ \\
315 & 57 & $\mathrm{D}$ & $\mathrm{D}$ & $\mathrm{D}$ \\
\hline
\end{tabular}

$\mathrm{N}^{\mathrm{a}}=$ no toxicity detected

$\mathrm{D}^{\mathrm{b}}=$ Greater than $100 \%$

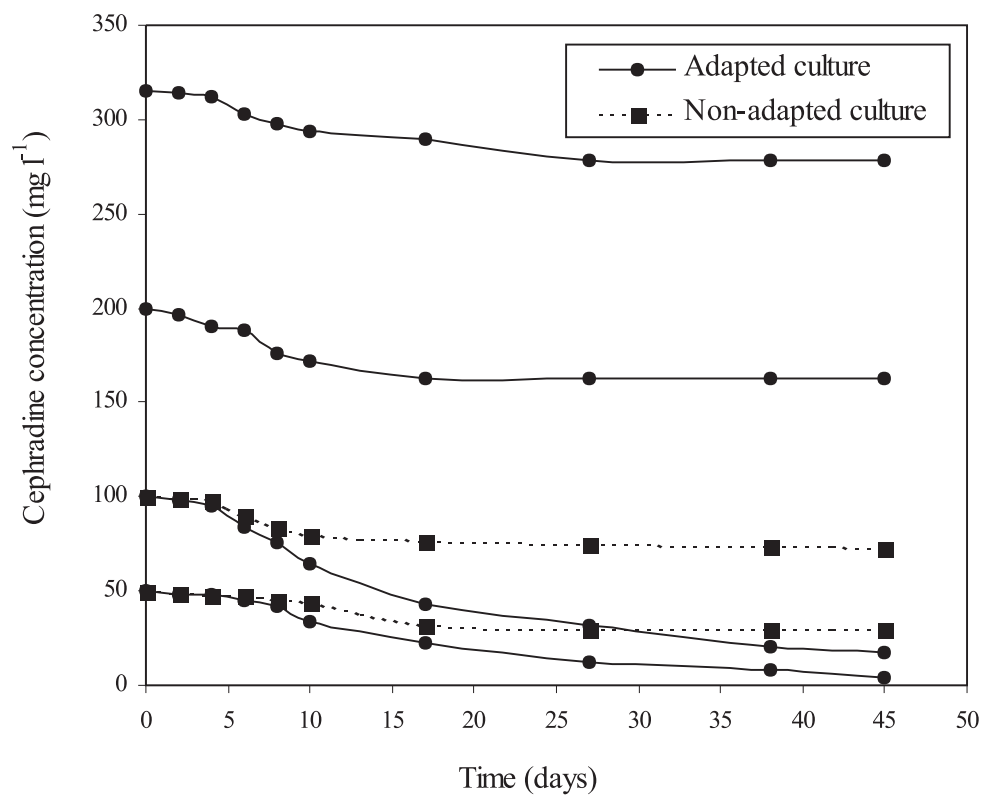

Figure 2. Variation of cephradine concentration in batch system with adapted and non-adapted cultures

\section{RESULTS AND DISCUSSION}

\section{Assessment of toxicity on anaerobic degradation of cephradine}

The toxicity due to anaerobic degradation of cephradine was assessed in the presence of Volatile Fatty Acid (VFA) as co-substrate in batch system using adapted and non-adapted cultures. The experiment was carried out in 2.51 bottles containing different concentrations of cephradine, $1000 \mathrm{ml}$ medium and VFA inoculated with adapted and non-adapted cultures. The cephradine concentrations chosen for the experimental study included 50, 100, 200 and $315 \mathrm{mg} \mathrm{l}^{-1}$. The adapted culture (Culture A) was able to degrade cephradine at all the concentrations with higher rate degradation at 50 and $100 \mathrm{mg} \mathrm{l}^{-1} \mathrm{com}-$ pared to 200 and $315 \mathrm{mg} \mathrm{l}^{-1}$. The non-adapted culture (Culture B) could degrade cephradine only at 50 and $100 \mathrm{mg} \mathrm{l}^{-1}$ concentrations. The variation of cephradine in batch system with adapted and non-adapted cultures were shown in Figure 2. It was inferred from the Figure 2 that the cephradine concentrations of 200 and $315 \mathrm{mg} \mathrm{l}^{-1}$ was found to be toxic to the adapted culture and the degradation did not take proceed after 27 th day. The toxicity values were evaluated in terms of Microtox testing using Photobacterium phosphoreum and the results were represented in the form of EC50 (effective concentration - the concentration responsible for a $50 \%$ reduction in the light output by Photobacterium phosphoreum). The samples of cephradine tested at different times were presented in the form of EC50 in Table 2. 
The term degradation of cephradine is referred to the degradation to its intermediates namely, 7amino-3-deacetoxycephalosporanic acid (7ADCA) and penicillic acid in the presence of in the presence of cultures. The degradation of cephradine proceeds as per equation 1 and 2 .

$$
\begin{aligned}
& \text { Cephradine } \\
& \left(\mathrm{C}_{16} \mathrm{H}_{19} \mathrm{~N}_{3} \mathrm{O}_{4} \mathrm{~S}\right) \\
& \text { Adapted Culture } \\
& \text { 7-amino-3-deacetoxycephalosporanic acid } \\
& \begin{array}{cl}
(7-A D C A) & \left(\mathrm{C}_{10} \mathrm{H}_{12} \mathrm{~N}_{2} \mathrm{O}_{5} \mathrm{~S}\right) \\
+
\end{array} \\
& \text { Penicillic acid }\left(\mathrm{C}_{8} \mathrm{H}_{1} 0 \mathrm{O}_{4}\right) \\
& \text { Penicillic acid Anaerobic degradation } \\
& \left(\mathrm{C}_{8} \mathrm{H}_{10} \mathrm{O}_{4}\right) \\
& \mathrm{CH}_{4}+\mathrm{CO}_{2}+\mathrm{H}_{2} \mathrm{O}
\end{aligned}
$$

The intermediates of cephradine viz., 7-amino-3deacetoxycephalosporanic acid (7-ADCA) and penicillic acid formed during the batch study under different concentrations (cephradine: 50, 100 and $200 \mathrm{mg} \mathrm{l}^{-1}$ ) using adapted and non-adapted cultures were shown in Figure 3. It was observed that the intermediates were well accumulated at concentrations of 50 and $100 \mathrm{mg} \mathrm{l}^{-1}$ in both adapted and nonadapted culture systems. The maximum concentrations of (7-ADCA) and penicillic acid were respectively found to be 13 and $12 \mathrm{~m} \mathrm{l}^{-1}$ at $100 \mathrm{mg} \mathrm{l}^{-1}$ of cephradine. The non-adapted cultures developed resistance and did not degrade cephradine beyond $100 \mathrm{mg} \mathrm{l}^{-1}$. The adapted culture degraded cephradine to only 7-ADCA even at $315 \mathrm{mg} \mathrm{l}^{-1}$ concentra-

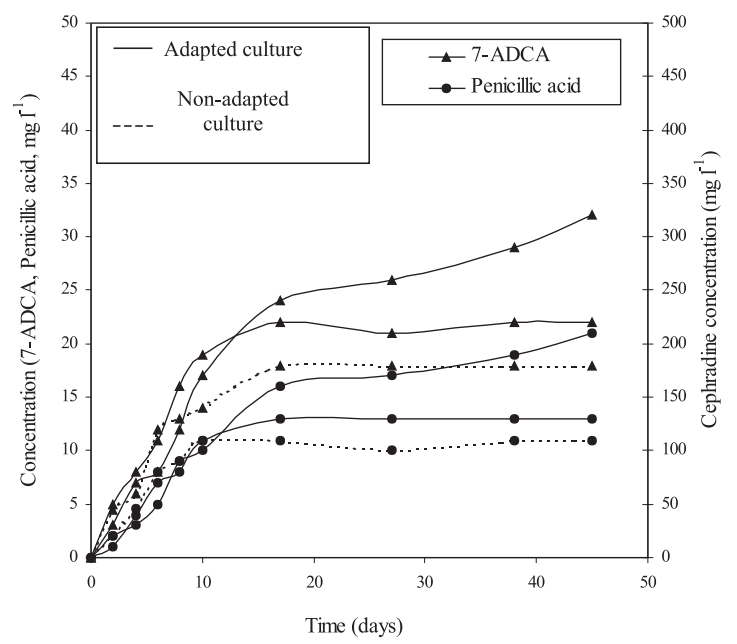

Figure 3. Biodegradation of cephradine in batch system with adapted and non-adapted cultures tion and did not produce penicillic acid and hence no yield of methane was observed. Hence, the specific methanogenic activity was found to cease at $315 \mathrm{mg} \mathrm{l}^{-1}$ concentration. The specific methanogenic activity is represented in terms of the volume of methane gas produced $(\mathrm{ml})$ per gram of biomass [g VSS (Volatile Suspended Solids)] per day (ml $\left.\mathrm{CH}_{4} \mathrm{~g}^{-1} \mathrm{VSS} \mathrm{d}^{-1}\right)$. The specific methanogenic activity measured for different concentrations of cephradine (50, 100 and $200 \mathrm{mg} \mathrm{l}^{-1}$ ) using adapted and non-adapted cultures were shown in Figure 4. It was observed from the figure that the specific methanogenic activity was found to increase with increase in cephradine concentration and attained a maximum of $375 \mathrm{ml} \mathrm{CH}_{4} \mathrm{~g}^{-1} \mathrm{VSS} \mathrm{d}^{-1}$ at $100 \mathrm{mg} \mathrm{l}^{-1}$ using adapted culture. The activity was reduced at $200 \mathrm{mg} \mathrm{l}^{-1}$ concentration and completely ceased at $315 \mathrm{mg} \mathrm{l}^{-1}$ concentration and hence no curve was shown for $315 \mathrm{mg} \mathrm{l}^{-1}$ concentration.

\section{Start-up Experiments}

\section{Effect of Culture Composition}

As it can be seen from Figures 5 and 6, the anaerobic fluidized bed reactor reached a steady state at the end of 147 days with respect to maximum COD removal $(63 \%)$ and biogas yield $\left(18 \mathrm{l} \mathrm{d}^{-1}\right)$ using non-adapted culture and at the end of 107 days with a maximum COD removal $(70 \%)$ and biogas yield $\left(22.51 \mathrm{~d} \mathrm{~d}^{-1}\right)$ using adapted culture. This clearly showed that the start-up of the reactor carried out using adapted culture attained a faster steady state

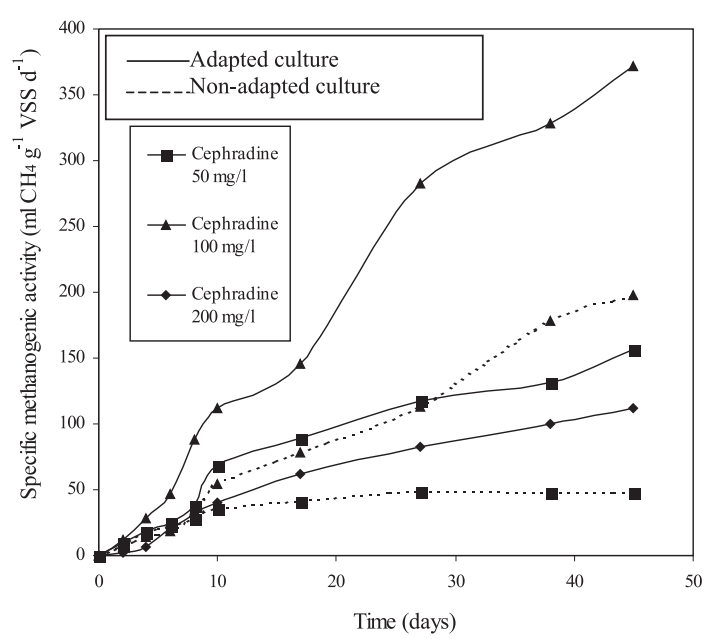

Figure 4. Specific methanogenic activity for cephradine degradation in batch systems. 


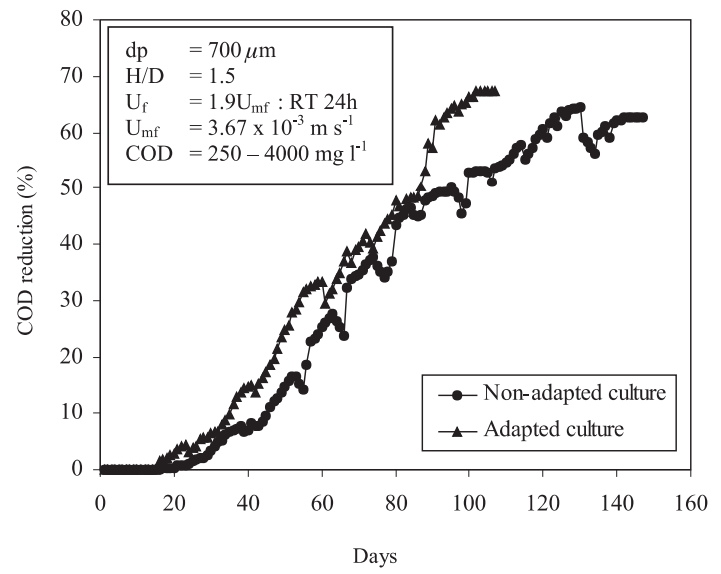

Figure 5. Variation of COD reduction (\%) during start-up of the reactor

with a higher COD removal (\%) compared to the reactor started using non-adapted culture.

The study of Kennes et al., (1997) reported a start-up period of 187 days using non-adapted culture and 122 days using adapted culture for synthetic para-cresol based effluent.

\section{Continuous Experiments}

\section{Bioaugmentation}

The term "bioaugmentation" refers to a method of maintaining sufficient biomass when adequate carbon substrates and nutrients are unavailable in the effluent (Babcock et al., 1992). The optimum value of COD/VSS ratio was decided based on the batch results of cephradine and VFA studied for toxicity assessment. The COD/VSS ratio studied for the bioaugmentation study included 0.15 , $0.2,0.3$ and 0.35 . The maximum concentration of the effluent was varied from $2000-4000 \mathrm{mg} \mathrm{l}^{-1}$. The effect of biomass addition in terms of COD/VSS ratio on COD removal (\%) is presented in Table 3 and in Figures 7 and 8 and the corresponding methane gas yields in Figures 9 and 10 using adapted and non-adapted cultures.

The decrease in the trend of the all the curves at 48 hours showed the addition of biomass at every $48 \mathrm{hrs}$ in the main reactor from enricher-reactor. The COD reduction (\%) was found to be higher in adapted culture with relatively low retention time as compared to non-adapted culture. The COD reduction $(\%)$ and methane gas yield were found to be 88.5 and $1.9 \mathrm{ld}^{-1}$ respectively at an

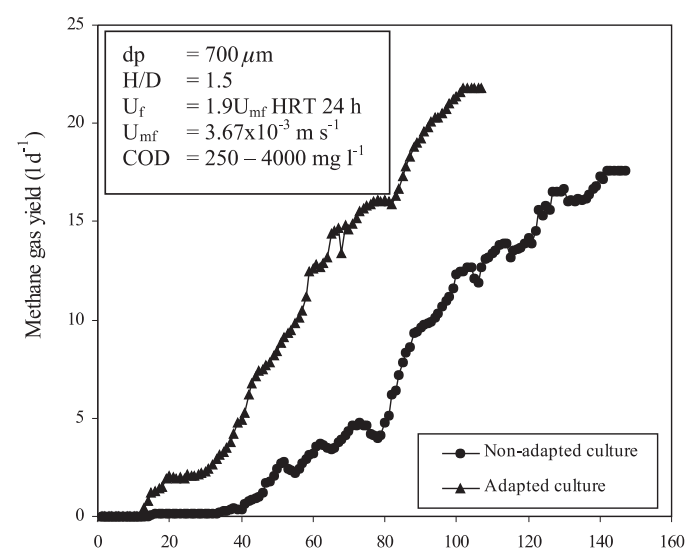

Figure 6. Variation of the methane gas yield during start-up of the reactor

HRT of $12 \mathrm{hr}$ using adapted culture with a COD/VSS ratio of 0.15 for a maximum COD concentration of $4000 \mathrm{mg} \mathrm{l}^{-1}$. For the same COD concentration, in case of non-adapted culture, COD reduction (\%) and methane gas yield were observed to be 78.5 and $1.51 \mathrm{~d}^{-1}$ at an HRT of 12 $\mathrm{hr}$ for a COD/VSS ratio of 0.15 . This was in general agreement with the experimental study of Kyoung et al., (1997) for the degradation of 1naphthylamine and Babcock et al., (1993) for the degradation of phenolic compounds (COD reduction (\%) 76.2 using adapted culture. In the study of Babcock et al. (1993), the maximum COD reduction $(\%)$ and methane gas yield were respectively found to be 82.3 and $1.91 \mathrm{ld} \mathrm{d}^{-1}$ for non-adapted culture (for a COD/VSS ratio of 0.15 ) and 91.2 and $5.621 \mathrm{~d}^{-1}$ for adapted culture or a COD concentration of $4000 \mathrm{mg} \mathrm{l}^{-1}$. The results showed that higher removal efficiency could be achieved at relatively higher concentrations in the presence of acetic acid as a co-substrate.

\section{CONCLUSION}

The assessment of toxicity was carried out in terms of specific methanogenic activity on anaerobic degradation of cephradine with Volatile Fatty Acid (VFA) as co-substrate in batch systems using adapted and non-adapted cultures. The effect of bioaugmentation was studied on anaerobic treatment of anti-osmotic drug based pharmaceutical effluent in continuous mode with adapted and non-adapted cultures using a fluidised bed reactor. 


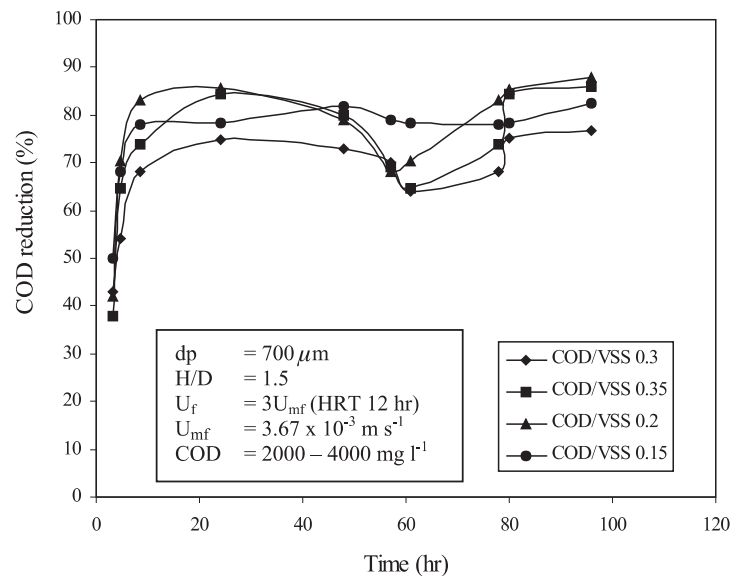

Figure 7. Effect of bioaugmentation on COD reduction (\%) using adapted culture.

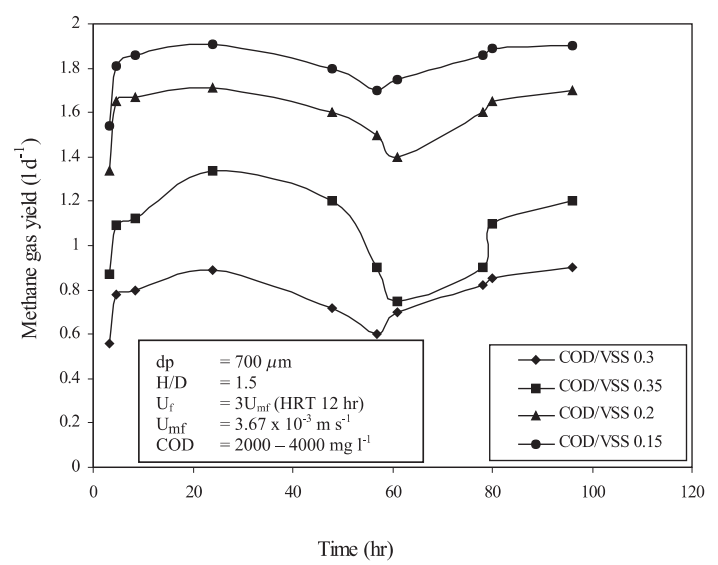

Figure 9. Effect of bioaugmentation on methane gas yield using adapted culture.

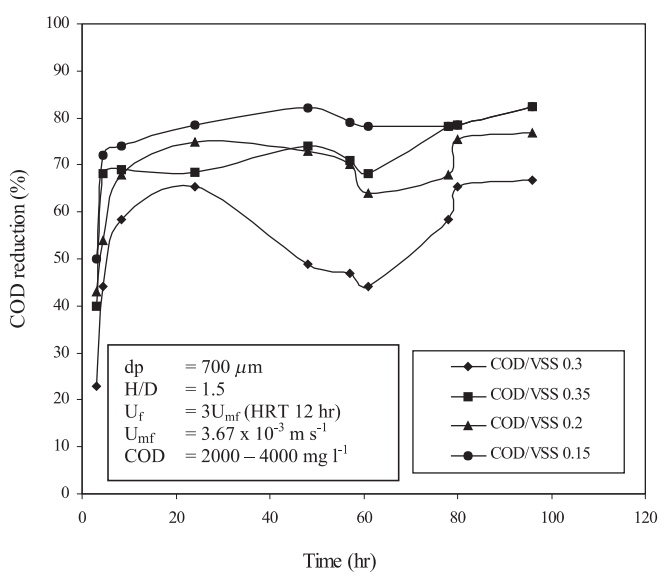

Figure 8. Effect of bioaugmentation on COD reduction $(\%)$ using non-adapted culture.

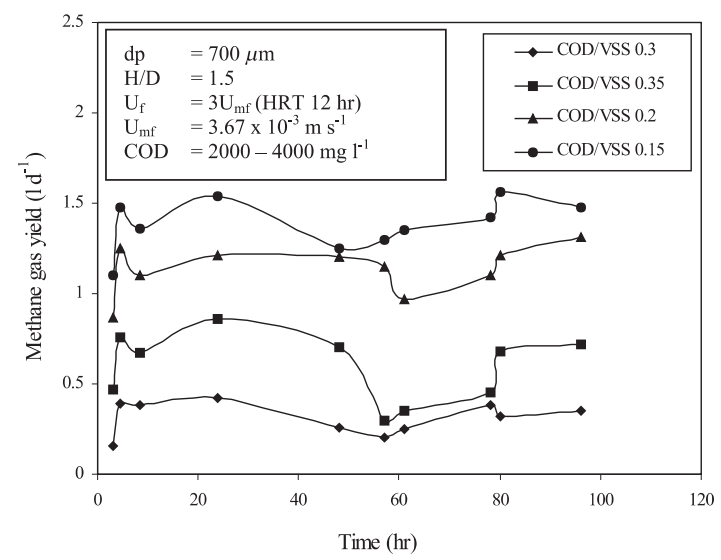

Figure 10. Effect of bioaugmentation on methane gas yield using non-adapted culture

Table 3. The effect of HRT on biomass growth using adapted and non-adapted cultures

\begin{tabular}{|c|c|c|c|c|c|c|c|}
\hline \multirow{2}{*}{ Sl.No } & \multirow{2}{*}{$\begin{array}{l}\text { HRT } \\
(\mathrm{hr})\end{array}$} & \multirow{2}{*}{$\mathrm{U}_{\mathrm{f}}^{\mathrm{a}}$} & \multirow{2}{*}{$\begin{array}{c}\text { Initial } \\
\text { pharmaceutical } \\
\text { influent } \\
\text { concentration } \\
\text { COD }\left(\mathrm{mg} \mathrm{l}^{-1}\right)\end{array}$} & \multirow{2}{*}{$\begin{array}{c}\text { Biomass } \\
\text { added } \\
\left(\mathrm{mgVSS} \mathrm{l}^{-1}\right)\end{array}$} & \multirow{2}{*}{$\begin{array}{c}(\mathrm{COD} / \mathrm{VSS}) \\
\text { ratio }\end{array}$} & \multicolumn{2}{|c|}{$\begin{array}{c}\text { Maximum COD } \\
\text { removal (\%) }\end{array}$} \\
\hline & & & & & & $\begin{array}{l}\text { Adapted } \\
\text { culture }\end{array}$ & $\begin{array}{l}\text { Non-adapted } \\
\text { culture }\end{array}$ \\
\hline 1 & 3.2 & $5.8 \mathrm{U}_{\mathrm{mf}}^{\mathrm{b}}$ & 2000 & 13332 & 0.15 & 70 & 80.3 \\
\hline 2 & 4.6 & $4.8 \mathrm{U}_{\mathrm{mf}}$ & 2500 & 12500 & 0.2 & 74 & 83.4 \\
\hline 3 & 8.4 & $3.8 \mathrm{U}_{\mathrm{mf}}$ & 3200 & 10665 & 0.3 & 76.2 & 86.2 \\
\hline 4 & 11.6 & $3.1 \mathrm{U}_{\mathrm{mf}}$ & 4000 & 11426 & 0.35 & 78.5 & 88.5 \\
\hline 5 & 24 & $1.5 \mathrm{U}_{\mathrm{mf}}$ & 2000 & 13332 & 0.15 & 83.2 & 91.2 \\
\hline
\end{tabular}

${ }^{\mathrm{a}} \mathrm{U}_{\mathrm{f}}=$ Fluidization velocity

${ }^{\mathrm{b}} \mathrm{U}_{\mathrm{mf}}=$ Minimum fluidization velocity 
The study has demonstrated that the use of off-line enricher-reactor to continuously inoculate the continuous flow reactor, overcomes the difficulty of growing adequate biomass on inhibitory or toxic substances or waste with too little carbon and nutrients to sustain a viable biomass, or other conditions that may not be conclusive to treatment. The results of the study conclusively demonstrated that bioaugmentation improves removal efficiency and reactor stability. The toxicity assessment was measured in terms of specific methanogenic activity $\left(\mathrm{ml} \mathrm{CH}_{4} \mathrm{~g}^{-1}\right.$ $\mathrm{VSS} \mathrm{d}^{-1}$ ), which was found to decrease with increase in cephradine concentration and attained a maxi- mum at $100 \mathrm{mg} \mathrm{l}^{-1}$. The COD reduction (\%) in continuous mode reached maximum of 88.5 at a Hydraulic Retention Time (HRT) of $12 \mathrm{~h}$ using bioaugmentation through periodic addition of 14 to $20 \mathrm{~g} \mathrm{l}^{-1}$ of biomass (acclimated cells) every 2 days from an off-line enricher-reactor.

\section{ACKNOWLEDGEMENTS}

Authors wish to acknowledge their sincere thanks to Orchid Pharmaceuticals Private Ltd., Chennai, India, for the supply of original pharmaceutical effluent required for the experimental work.

\section{REFERENCES}

Arbuckle, W. and Alleman, J. (1992), Effluent toxicity testing using nitrifiers and microtox, Wat. Environ. Res. 64, 263-267.

APHA-AWWA-WPCF (1995), Standard Methods for the Examination of Water and Wastewater, 19th edition, APHA, Washington, USA.

Babcock, R.W, Jr. Ro, K.S., Hsieh, C.C. and Stenstrom, M.K. (1992), Development of an off-line enricher reactor process for activated sludge degradation of hazardous wastes, Water Environ. Res. 64, 782-791.

Babcock, R.W. Jr., Chen W., Ro, K.S., Mah, R.A. and Stenstorm M.K. (1993), Enrichment and kinetics of biodegradation of 1-Naphthylamine in activated sludge, Appl. Micro. and Biotechnology, 39, 264-269.

Babcock, R.W. and Stensrom, M.K. (1993), The use of inducer compounds in the enricher reactor process for degradation of 1-Naphthylamine, Water Environ. Res. 65, 26-33.

Bisaillon, J.-G., L'epine, F., Beaudet, R. and Sylvestre, M. (1993), Potential for carboxylation-dehydrocarboxylation of phenolic compounds by a methanogenic consortium, Can. J. Microbiol. 39, 642-648.

Bossert, I.D., Rivera, M.D. and Yound, L.Y. (1986), p-Cresol biodegradation under denitrifying conditions: isolation of a bacterial coculture, FEMS Microbiol. Dcol. 38, 313-319.

Cardinal, L.C. and Stenstrom, M.K. (1991), Enhanced biodegradation of polyaromatic hydrocarbons in the activated sludge process, Research J. Water Environ. Fed. 63, 950-957.

Department of Health and Social Security, Scottish Home Health Dept., Welsh Office, Ministry of Health and Social Services for Northern Ireland (1980), British Pharmacopoeia, 1, 86-89, University Press, Cambridge.

Haggblom, M.M., Rivera M.D., Bossert, D., Rogers, J.E. and Young L.Y. (1990), Anaerobic biodegradation of para-cresol under three reducing conditions, Microb. Ecol. 20, 141-150.

Kennes, C., Mendez, R. and Lema, J.M. (1997), Methanogenic Degradation of Para-cresol in Batch and Continuous UASB Rectors, Wat. Res. 31, 1549-1554.

Kyoung, S.RO, Babcock, R.W. and Stenstrom, M.K. (1997), Demonstration of bioaugmentation in a fluidised bed process treating 1-Naphthylamine, Wat. Res. 31 , 1687-1693.

Lovely, D.R. and Lonergan, D.J. (1990), Anaerobic oxidation of toluene, toluence, phenol, and p-cresol by the dissimilatory iron-reducing organism, GS-15, Appl. Environ. Microbiol. 56, 1858-1864.

Microbics Corp. (1988), How to run a Standard MicrotoxTM Test. Booklet from Microbics Corp., Carlsbad, Calif.

Ramanand, K. and Sulflita, J. M. (1991), Anaerobic degradation of m-cresol in anoxic aquifier slurries. Carboxylation reactions in a sulfate-reducing bacterials enrichment, Appl. Environ. Microbiol. 57, 1689-1695.

Ramanand, K. and Sulflita, J.M. (1993), Carboxylation and mineralization of m-cresol by a sulfate-reducing bacterial enrichment, Current Microbiol. 26, 327-332.

Roberts, D.J. and Fedorak, P.M. (1987), Comparison of the fates of the methyl carbons of m-cresol and p-cresol in methanogenic consortia, Can. J. Microbiol. 33, 335-338.

Roberts D. J., Fedorak, P.M. and Hrudey, S. E. (1990), CO2 incorporation and 4-hydroxy-2-methlbenzoic acid formation during the anaerobic metabolism of m-cresol by methanogenic consortium, Appl. Environ. Microbiol. 56, 472-478. 
Suflita, J. M., Liang, L.N. and Saxena, A. (1989), The anaerobic biodegradation of o-, m-, and p-cresol by sulfatereducing bacteria enrichment cultures obtained from a shallow anoxic aquifier, J. Indust. Microbiol. 4, 255-266.

Tschech, A. T. and Fuchs, G. (1987), Anaerobic degradation of phenol by pure cultures of newly isolated denitrifying pseudomonas, Arch. Microbiol. 148, 213-217. 